\title{
Analysis of Drinking Water Quality in Industrial Area Phagwara, Punjab (India)
}

\author{
${ }^{1}$ Smriti Tuteja, ${ }^{2}$ Savneet Kaur \\ ${ }^{1} P G$ Scholar, ${ }^{2}$ Assistant Professor, \\ Department of Chemistry, School of Engineering \& Applied Sciences, \\ Desh Bhagat University,Mandi Gobindgarh, Punjab, India \\ Email: ${ }^{1}$ smritituteja75@gmail.com \\ ${ }^{2}$ kailleysavneet@gmail.com
}

\begin{abstract}
:-
It is evident that many parts of the Industrial areas in India are colonized and in very close vicinity of the industries and are using groundwater for drinking and domestic purposes. The drinking water should be pure, free from contamination and harmful chemicals. Quality of water can be defined in terms of physical and chemical parameters. The various physicochemical parameters are affected by the industrial effluents. The study aimed to assess the impact of industrial activities on drinking water in Phagwara region of Kapurthala district. It throws a light on physico chemical analysis of tubewell water in and around the industries. Various physico-chemical parameters like color, odor, taste, pH, TDS (Total dissolved solids), TH (Total Hardness) Turbidity, EC (Electrical Conductivity), Total alkalinity were analyzed. The observed values were compared with BIS (2012) and WHO Standards. Results showed that water quality parameters were within the acceptable limit (normal range), but $\mathrm{pH}$, alkalinity and hardness were above the acceptable limit. Water is fit for drinking. It is suggested that water quality should be monitored regularly to avoid any contamination.
\end{abstract}

Keywords: - Physicochemical characteristics, water quality, industrial area.

\section{Introduction}

Water is one of the most important and precious natural resources. It is of vital importance in human life. Water is most abundant compound (70\%) on earth's surface. It is significant due to unique physical and chemical properties ${ }^{[1-4]}$.

It is incredibly and indispensible for human life. Safe drinking is essential for life and a satisfactory supply must be made to consumers ${ }^{[5]}$. The WHO ${ }^{[6]}$ revealed that seventy five percent of all diseases in developing countries arise from polluted drinking water. Groundwater is the definitive and most fit freshwater resources with trace concentration of the salts for consumption by humans ${ }^{[7]}$. Mahmoud et.al stated that most common problems in household water supplies may be attributed to hardness, iron, sulphide, sodium, chloride, alkalinity, acidity and disease producing pathogens such as bacteria and fungi. International and local agencies have established parameters to determine biological and physicochemical quality of drinking water ${ }^{[8]}$. Acceptable quality shows the safety of drinking water in terms of physical and chemical parameters ${ }^{[8,9]}$. 


\section{Literature Review}

Water is the elixir of life. It is the major constituent of all living bodies water makes up two third of the human weight ${ }^{[10]}$. About 780 million people do not have access to clean and safe water and about 2.5 billion people do not have proper sanitation. Around 4 million people die each year due to water related diseases and disasters ${ }^{[11]}$. According to the World Health Organization (WHO), drinking contaminated water is one of the major causes of diarrheal diseases, which make up the second leading cause of child mortality resulting in the deaths of about 760,000 children aged below 5 years annually. For this reason, the WHO has identified the lack of access to clean drinking water as the most critical factor that negatively influence the general health and well being of population in developing countries ${ }^{[12] . ~ O v e r a l l ~ p r o v i s i o n ~}$ of safe drinking water can help to reduce or eliminate preventable deaths emanating from water borne diseases ${ }^{[13]}$. Access to safe drinking water \& sanitation is a global concern. Water quality and suitability for use are determined by its taste, color, odor, turbidity and concentration of organic and inorganic matters ${ }^{[14]}$. Contaminants in water can affect its quality and consequently the human health ${ }^{[15]}$. Keeping in view the literature review, attempts have been made to study parameters of drinking water. Various technical research papers on physico -chemical characteristics of drinking water were carried out in this study are given below:

Md. Aminur Rahman et al. ${ }^{[16]}$ carried out physico -chemical and bacteriological analysis of drinking tube-well water from some primary schools-Magura, Bangladesh to evaluate suitability for students. The drinking water samples from twenty primary schools were tested. The results showed that about 35\% tubewells were found to be polluted with FC and others $70 \%$ with TC. Drinking water samples were not safe for human consumption and could cause diarrheal diseases.

Sudhir Yadav and Arvind Kumar ${ }^{[17]}$ did the research on physico-chemical analysis of water of Triveni Sugar Mill (Ramkola). The analysis was done for getting the knowledge of physical and chemical properties of water that is coming out from the sugar-mill which is located in Ramkola, Kushinagar, UP. All the parameters were within the permissible range.

G.S. Gaikwad, Atul.V. Wankhade and Atul V. Maldhure [18] studied on the hydrochemical characteristics of ground water (well \& tubewell) in the slum area of Bhoogaon, Wardha district of Mahrashtra state, water samples were collected and analyzed. The results showed that most of the ground water samples were of good quality and were within the permissible limit prescribed by BIS (1991) for $\mathrm{pH}$, Turbidity, TS, Total Hardness etc.

H.H. Oyem, I.M.Oyem and D. Ezeweali [19] studied the Temperature, pH, Conductivity Total dissolved solids in ground water of Agbor/Owa town and immediate suburbs were studied. The parameters were analyzed for $\mathrm{pH}, \mathrm{EC}$, TDS and COD resp. It was found out that groundwater is of good quality with values below the guidelines of WHO, USEPA and Nigerian Water Safety Standard. 


\section{Material and Methods:-}

3.1 Geographical Location:- Phagwara is the prominent Industrial centre in the Kapurthala district of Punjab. It is located on the National highway 44 and located 124 Kilometres away from Chandigarh and 20 Kilometres away from Jalandhar. It is an area of $20 \mathrm{~km}^{2}$ (approx) in Kapurthala district.

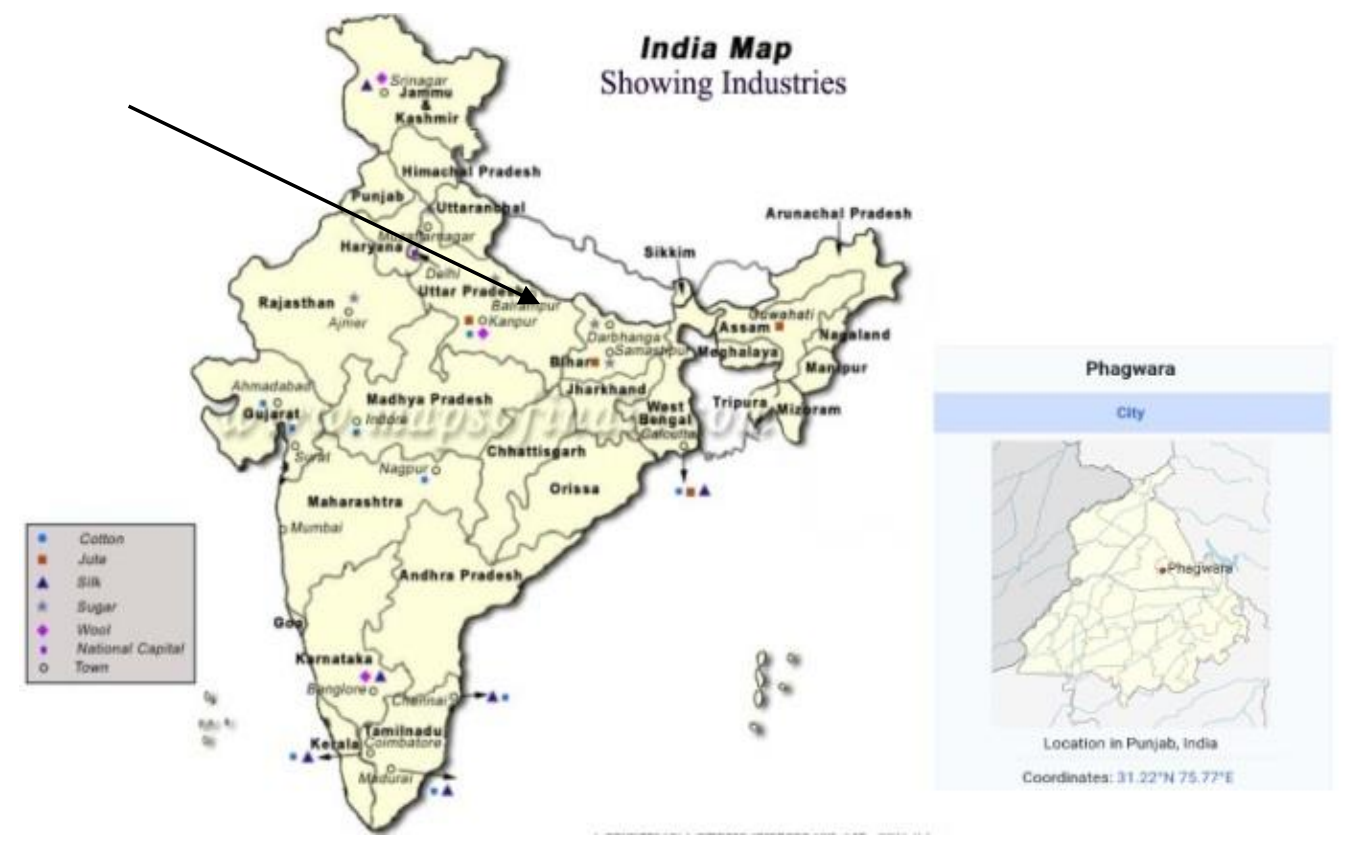

Co-ordinates: $31.22^{\circ} \mathrm{N}$ and $75.77^{\circ} \mathrm{E}$. It is on the land between Beas and Sutlej rivers and is typical Doaba City. It has an average elevation of 767 feet $(234 \mathrm{~m})$.

3.2 Area of Study:- Phagwara owes its significance due to diverse group of industries like Wahid Sandhar Sugar Mill, Sukhjit Starch and Chemicals Ltd., Diary industries etc are found here. These industries release industrial effluents, which contain toxic chemicals, hazardous compounds, suspended solids and non-biodegradable materials and pollute the groundwater in and around the Industrial area. The discharged chemicals interact with the ground water and alter the $\mathrm{pH}$ and water quality parameters. Hence, Industrial area was selected to study the effect of effluents on water quality.

\subsection{Collection and analysis of samples}

The main elements of water quality monitoring are collection and analysis of water samples, the study and evaluation of the analytical results and reporting of the findings. The purpose of monitoring was to gather sufficient data (by sampling and analysis) and to assess the quality of drinking water in the Industrial Town. Tube well water samples were collected from different places around the Sugar Mill, Starch Mill and Dairy Industry. The following guidelines for water quality monitoring were followed while collecting the water samples.

* The bottles containing the water samples were rinsed three times before they were filled.

* A small air space was left in the bottles to allow mixing of the samples.

* The sample bottles were labelled properly, by attaching a label on each bottle.

* Analysis of sample was done within 24 hours of collection. 
The following is the list of areas from where the sample were collected:-

\begin{tabular}{|c|c|c|}
\hline Sample No. & Source & Area /Location \\
\hline T-1 & Tubewell & Sugar Mill \\
\hline T-2 & Tubewell & Temple near Sugar mill \\
\hline T-3 & Tubewell & Railway Road \\
\hline T-4 & Tubewell & Starch Mill \\
\hline T-5 & Tubewell & Street Near Starch Mill \\
\hline T-6 & Tubewell & Gaushalla Market \\
\hline T-7 & Tubewell & Bus Stand \\
\hline T-8 & Tubewell & Dairy Industry \\
\hline
\end{tabular}

The samples of various locations were analyzed with respect to physiochemical parameters such as pH, TDS (Total dissolved solids) TH (Total Hardness), Turbidity, EC (Electrical Conductivity) \& Total Alkalinity. Standard method for the examination of water and wastewater by APHA (2012) and Standard Method of Sampling and Test (Physical and Chemical) for water and wastewater by BIS (1984) were used for analysis of various physicochemical parameters.

\section{Results and Discussion}

In order to assess the physicochemical study of tubewell water from different areas in the Industrial town, the obtained results were compared with BIS (2012) and WHO guidelines. The analyzed values of each parameter is discussed below and shown in Table 4(a).

Color: - The water samples from all tubewell were found to be colorless and clear. Color was observed by visual method by taking the samples in clean test tube.

Taste: - Water was tasteless in all the samples.

Odor: - Odor is determined soon after collecting the samples in pre-washed bottles. The bottles were shaken vigorously for 2-3 seconds. By smell, water was found to be odorless in all the samples.

$\mathbf{p H}$ :- Measurement of $\mathrm{pH}$ relates to the acidity or alkalinity of water ${ }^{[21]} \cdot \mathrm{pH}$ was measured by portable $\mathrm{pH}$ meter and was calculated before use. The $\mathrm{pH}$ of all the samples was recorded turn by turn. It ranged from 7.5 to 8.2 . The $\mathrm{pH}$ was found to be slightly alkaline.

Electrical Conductivity (EC):- Conductivity is the measure of the ability of water to carry electric current. It was measured by conductivity meter. Conductivity value ranged from 406 to $516 \mu / \mathrm{cm}$ at different sampling sites.

\section{Total Dissolved Solid (TDS)}

The terms TDS describes all dissolved solids (usually mineral salts) in water. The acceptable limit of TDS is $500 \mathrm{mg} / \mathrm{l}$ (BIS, 2012) ${ }^{[18]}$. TDS of water samples in the present study varied from $217 \mathrm{mg} / \mathrm{l}$ to $324 \mathrm{mg} / \mathrm{l}$, which is also measured by conductivity meter.

Turbidity: The suspension of particles in water interfering with passage of light is called turbidity. It is caused by wide variety of suspended particles. It is measured by turbidity meter. The values of the samples were between $<1$ to 1.3 . 
Total Hardness: Hardness mainly depends upon the amount of calcium or magnesium salts or both. It is the property of water which prevents the formation of lather with soap and increases the boiling point of water. BIS desirable limit for total hardness is $200 \mathrm{mg} / \mathrm{l}^{[18]}$. It was tested by EDTA titration method.

The highest and lowest values of total hardness were observed at samples T-4 as 501 and T-3 as 420 respectively, which are all measured by titration. The tubewell samples T-1 and T-4 taken from sugar mill and starch mill showed higher hardness values.

Total Alkalinity: Alkalinity is the sum of total components in the water that tend to elevate the $\mathrm{pH}$ to the alkaline side of neutrality. It is measured by titration with standardized acid to a $\mathrm{pH}$ value of 4.5 and is expressed commonly as milligrams per liter as calcium carbonate $\left(\mathrm{mg} / \mathrm{l}\right.$ as $\left.\mathrm{CaCO}_{3}\right)$ Commonly occurring material in water that increase alkalinity are carbonates, phosphates and hydroxides ${ }^{[22]}$. According to BIS Standard acceptable limit and permissible limit of total alkalinity are $200-600 \mathrm{mg} / \mathrm{l}$. Total alkalinity of water samples ranged from 315 to $333 \mathrm{mg} / \mathrm{l}$. It was slightly alkaline in nature but within the permissible limit.

\begin{tabular}{|c|c|c|c|c|c|c|c|c|c|c|c|}
\hline \multirow[t]{2}{*}{ S.No. } & \multirow[t]{2}{*}{ Parameters } & \multicolumn{2}{|c|}{$\begin{array}{c}\text { Bureau of Indian } \\
\text { Standard (IS- } \\
\text { 10500:1994) }\end{array}$} & $\begin{array}{c}\text { SITE } \\
1\end{array}$ & $\begin{array}{c}\text { SITE } \\
2\end{array}$ & $\begin{array}{c}\text { SITE } \\
3\end{array}$ & $\begin{array}{l}\text { SITE } \\
4\end{array}$ & $\begin{array}{l}\text { SITE } \\
5\end{array}$ & $\begin{array}{c}\text { SITE } \\
6\end{array}$ & $\begin{array}{c}\text { SITE } \\
7\end{array}$ & $\begin{array}{c}\text { SITE } \\
8\end{array}$ \\
\hline & & $\begin{array}{l}\text { Acceptable } \\
\text { limit }\end{array}$ & $\begin{array}{c}\text { Permissible } \\
\text { Limit }\end{array}$ & $\mathrm{T}-1$ & $\mathrm{~T}-2$ & $\mathrm{~T}-3$ & $\mathrm{~T}-4$ & T-5 & T-6 & $\mathrm{T}-7$ & $\mathrm{~T}-8$ \\
\hline 1 & Color & Agreeable & Agreeable & Agr & Agr & Agr & Agr & Agr & Agr & Agr & Agr \\
\hline 2 & Taste & Agreeable & Agreeable & Agr & Agr & Agr & Agr & Agr & Agr & Agr & Agr \\
\hline 3 & Odor & Agreeable & Agreeable & Agr & Agr & Agr & Agr & Agr & Agr & Agr & Agr \\
\hline 4 & $\mathrm{pH}$ & 6.5 & 8.5 & 8.2 & 8.1 & 8.0 & 7.5 & 7.9 & 8.0 & 7.9 & 8.1 \\
\hline 5 & Turbidity & 1 & 5 & $<1$ & 1.2 & 1.3 & 1.2 & $<1$ & 1 & 1.3 & 1 \\
\hline 6 & $\begin{array}{l}\text { Electrical } \\
\text { Conductivity }\end{array}$ & 700 & 3000 & 515 & 437 & 448 & 406 & 492 & 445 & 419 & 5.16 \\
\hline 7 & $\begin{array}{l}\text { Total } \\
\text { dissolved } \\
\text { Solids }\end{array}$ & 500 & 2000 & 255 & 217 & 222 & 302 & 298 & 324 & 258 & 258 \\
\hline 8 & $\begin{array}{l}\text { Total } \\
\text { hardness } \\
\mathrm{mg} / \mathrm{l}, \max \end{array}$ & 200 & 600 & 500 & 440 & 420 & 501 & 480 & 460 & 440 & 480 \\
\hline 9 & $\begin{array}{l}\text { Alkalinity } \\
(\mathrm{mg} / \mathrm{l})\end{array}$ & 200 & 600 & 333 & 330 & 325 & 315 & 315 & 317 & 333 & 332 \\
\hline
\end{tabular}

Table 4 (a): Results of Physicochemical analysis of Tubewell water sample 


\section{Conclusion:}

With respect to above the tests the water quality parameters such as color, taste, odor, turbidity, electrical conductivity, total dissolved solids (TDS) are within the acceptable limit. But the parameters $\mathrm{pH}$, alkalinity and total hardness is slightly higher above the acceptable limit as compared with BIS and WHO standards. It is concluded that water in the Industrial area is fit for drinking and domestic use, from selected areas of study.

As water is affected by the industrial effluents which alter the parameters of water and cause risk of various health hazards to population. Therefore, it is necessary to analyze the water quality. It is suggested that water should be treated and monitored regularly to avoid any contamination.

\section{Reference}

1) Aryal J., Gautam B, Sapkota N. Drinking water quality assessment, J, Nepal. Health Res Counc, 2012, 10(22):192-196.

2) Onifade AK, Llori RM, Microbiological analysis of sachet water vended in Ondo state, Nigeria. Environ Res J, 2008, 2: 107-110.

3) Osci Y, New School Chemistry for Senior Secondary Schools. African first publisher Ltd, Onitsha, $3^{\text {rd }}$ edn, 2005, p:292.

4) Obi CN, Okocha Co, Microbiological and Physicochemical analysis of selected borehole waters. Journal of Engineering Applied Sciences, 2007, 25(7):920-929.

5) Ackah M, Anim AK, Gyamfi ET, Acquah J, Nyarko ES, Assessment of quality of sachet water consumed in Urban townships of Ghana using the physico-chemical indicators: a preliminary study. Advances in Applied Science Research, 2012, 3(4):2120-2127.

6) WHO, Disinfectants and disinfectant byproducts. Environmental health criteria 216, Geneva; World Health Organization, 2006.

7) Yadav, KK., Neha G, Vinit K, Physico- Chemical analysis of water in Agra City, India. Recent Res Sci Technol, 2012; 4(11): 51-54.

8) Havelaar, A., Blumenthal, UJ, Strauss M, Kay D, Bartram J, Water quality: Guidelines, standards and Health, 2001, pp: 17-42.

9) WHO (2004): Guidelines for drinking water quality, Geneva; World Health Organization.

10) Saleh, MA., Emmanuel, E., Joseph, J. Wilson BL, Chemical evaluation of commercial bottled drinking water from Egypt. Journal of Food Composition and Analysis, 2001, 14(2):127-152.

11) Jackson, R.B., Carpenter, SR., Dahm, CN., Mc Knight, DM., Naiman, RJ., Postel, SL and Running, SW, Water in changing world, Issues in Ecology.Ecol Soc Am, 2001, 1-16.

12) Kumar N, A view on fresh water environment, Ecol, Eun, and Cons, 1997, 3-4.

13) Lavson EO, Physico-Chemical parameters and heavy metal contents of water from the Mangrove swamps of Lagos Lagoon, Lagos Nigeria ,Adv Biol Res, 2011,(5):8-21.

14) Manjare,SA., Vhanalakar, SA and Mulley DV, Analysis of water quality using physicochemical parameters of Tamdalge. Tank in Kohlapur District, Maharashtra, International Journal of Advanced Biotechnology and Research 2010, 1(2):115-119. 
15) Meride $Y$ and Ayenew B, Drinking water quality assessment and its effects on residents health in Wondo Genet Campus, Ethiopia Meride and Ayenewe Environ Syst Res, 2016, 5(1):1-7.

16) Md Aminur Rahman., Md Monirul Islam, Firoz Ahmad, Physico Chemical and bacteriological analysis of drinking tubewell water from primary schools, Magura, Bangladesh Journal of Applied sciences and Engineering Research, 2015, 4(5).

17) Sudhir Yadav, Arvind Kumar, Physico-Chemical Analysis of Triveni Sugar Mill (Ramkola), International Journal of Science and Research (IJSR),2019, 8(6): 119-120.

18) G.S. Gaikwad, Atul.V. Wankhade and Atul V. Maldhure, Hydro chemical characteristics of ground water (well \& tubewell) in the slum area of, Wardha district of Mahrashtra, Journal of Chemical and Pharmaceutical Research (ISSN; 0975-7384).

19) H.H. Oyem, I.M.Oyem and D. Ezeweali studied the Temperature, pH, Electrical Conductivity Total dissolved solid and Chemical oxygen demand of groundwater in Boji-Boji Agbor/owa area and immediate suburbs . Research journal of Environmental science, 2014, 898):444450.

20) Sarala C, Ravi Babu P, Assessment of Groundwater quality parameters in and around Jawaharnagar, Hyderabad. International Journal of Scientific, Research publications, 2012, 2(10), ISSN 2250-3153.

21) Devendra Dohare, Shriram Deshpande and Atul Kotiya, Analysis of Ground Water Quality Parameters: A Review Research Journal of Engineering Sciences, 2012, 3(5):26-31.

22) Hulawale Nayan $R$, Assessment of water quality by physico-chemical parameters, International Research Journal of Science \& Engineering, 2018,ISSN: 2322-0015. 